\title{
The Analysis of Competitiveness of University Graduates in the Labor Market: The Case of Latvia
}

\author{
Daina Vasilevska ${ }^{1}$, Tatyana Golubkova, ${ }^{2, *}$ \\ ${ }^{1}$ International College of Business and Finance, Riga, Lomonosova street 1/4, Latvia \\ ${ }^{2}$ Baltic International Academy, Riga, Lomonosova street 4, Latvia \\ *Corresponding Author: ebsi-golubkova@inbox.lv
}

Copyright $(92014$ Horizon Research Publishing All rights reserved

\begin{abstract}
Market conditions, as well as the qualitative changes of field of activity of modern specialist - graduate requires from the higher education institution a significant increase of the quality of its education, bringing to the foreground such characteristics of graduates as "competiveness". What should be the institutional specialist training in order to provide them an opportunity to implement their personal and professional potential, simultaneously satisfying the needs of society? The answer to this question involves two main points: 1) Requirements determination to the future specialist on the part of his/her personality, state and society; 2) The choice of the educational technologies that meet these requirements; The higher education system is being developed now in the context of market reforms therefore it becomes possible and necessary to apply to its functioning some of the economic categories, such as "market", "goods", "demand", "supply", "competition", "competiveness", "marketing". In the article the authors examined the correlation of these concepts in relation to the main result of the activity of universities graduate, the future specialists and also tried to find the answer to the question whether it is needed today to our labor market young specialists.
\end{abstract}

Keywords Young Specialists, Labor Market, Competiveness, Emigration

\section{Introduction}

Quality of education of students graduating from universities, where the main criterion is professional competence, is reviewed in the light as recommended by UNESCO [1]. The substance of the requirements for professional competence involves the extension of knowledge, skills and abilities, which are directly required for the development of labor productivity and for life-sustaining activities in general. This is not only a concept of purely occupational and industrial knowledge, skills and abilities. Requirements are set for a variety of knowledge, skills and abilities, including those necessary for maintenance and development of traditions and culture, rational use of nature resources, environmental protection and reduction of the environmental risk, and competitive power in the labor market. One of the distinctive features of the concept of personal competence is expansion of an individual's role in social changes, in ability to understand the dynamics of development processes and influence of their course. These requirements for professional competence are determined by the national education policy. What sort of university-level training of specialists should be provided to enable them to fulfill their personal and professional potential, alongside with satisfying the needs of the society? Obviously, there is no unambiguous answer to the question. The answer to the above question deals with two major issues:

1. Setting requirements for the prospective specialist on the part of the person, individual market participants, the state and the society;

2. Selecting education technology meeting such requirements.

Higher education system is currently developing in the context of market transformation, therefore it has become possible and necessary to apply specific economic categories to its functions, such as market, goods, demand, supply, competition, competitive ability and marketing. We will attempt to review the interrelations of these notions as regards the major results of university activities: the graduate and potential specialist.

\section{Relevancy of the Research}

Changes occurring in the social and economic sphere of the society and development of market relations in particular, have led to a conceptually new situation in the area of higher education. Today, when the supply of the labor force considerably exceeds the demand, only those specialists who are able to meet competition are sought after in the labor market. Market conditions, as well as the expansion and quality change of the scope of activities of the present-day 
university graduate specialists require educational establishments considerably improve the quality of education, they provide by bringing the competitive ability of the graduates to the forefront. The analysis of the scientific publications shows that the issue of competitive ability of prospective specialists is being studied, with a different degree of completeness and specificity, in relation to the problematics of the continuous professional trailing of skilled specialists in diverse educational establishments. It is evident that the notion of professionalism in pedagogics is currently more developed than the notion of competitive ability. At the same time, scientists take a keener interest in the issue of competitive ability of the present-day specialist and the formation of such ability in the course of receiving education. The studied issues include economic, social, professional, psychological and professional pedagogical aspects of competitive ability. Owing to the efforts of scientists representing various fields, the essence of a specialist's competitive ability is now generally reviewed as readiness to participate in competition relying upon professional and personal resources, individual and personal resources, and moral and spiritual resources. A specialist who is able to meet competition is reviewed not only as a product of the educational establishment, but also as a personality possessing certain qualities; allowance is made not only for the high level outcome of his or her activities, but also for the ability to endure the competitive battle and to come off the winner. Thus the present-day university faces a very important task of not only providing the prospective specialist with a set of professional knowledge, skills and abilities, but also enabling students to build the ability to come forward in the labor market and the capability to provide optimal, flexible and efficient solutions to problems, which occur at any time and under any circumstances. Although providing a rather high level of professional education on the whole, the higher education system of Latvia has incorporated the objective of forming competitive specialists into the list of major tasks to be solved by universities only since the 1990s. Today, the relevancy of solving this problem is manifest in the state programme for the development of education which shows the social significance of this issue and requires a purposeful elaboration of the fundaments for its solution in the system of higher education [2].

\subsection{Formation of Competitive Ability of Evaluation in a University Graduate}

Today in Europe, higher education is becoming one of the areas of rapid formation of new approaches for the organization and management, aimed at improvement of efficiency, dynamics, as well as adaptive and developmental capabilities. Therefore the principles of university activities are becoming more appropriate to those which are used in business sphere. The achievements for an university, however, do not come down to a merely financial and commercial effect: they involve several factors. This is recognition of the significance of the specific university and hiring ability of its graduates by the public. The university has interest in the utmost compliance of its education services to the requirements of the labor market. Firstly, the labor market determines the main quality standards of education, thus changing the demand for specialists in one or another area and defining more precisely knowledge and skills which applicants for the certain vacant positions should possess. Secondly, employment prospects are an important reason predetermining the choice of the university by the consumer (the 83 student). As a result of consuming education services provided by the university, as well as individual effort and influence on the part of family, environment, national culture etc., a university graduate acquires qualities and characteristics which are capable of satisfying a company's needs for the labor force of the required level and skills. The more distinctive features of the consumed education services are manifest in the graduate's professional qualities and characteristics and the more precisely these features comply with the employers' requirements, the bigger is the response which the university receives from the target segment of the labor market hiring the graduates. This response is evident in tangible and intangible benefits gained by the university: growth of prestige, obtaining funds, increased demand for the rendered education services etc. If graduates repeatedly seek education products offered by the university (continuing education on a higher level, advanced training programs etc.), they become consumers once again. The performed analysis of the existing requirements of the present-day European labor force market has made it possible to create a model of a young specialist. This model can be described using the terms offered by P.Kotler: core product, actual product and augmented product [3].In the context of this article, it is possible to see how a young specialist selling himself or herself in the labor market as a product.

It may be said that by hiring a specialist, the employer buys hope for the professional performance of the job. These are the needs which form the core product. Reviewing a specialist's model - the core product - as a unity of special knowledge and skills stipulated by the national standard regarding the relevant specialization, it becomes clear that this is not enough for reaching a certain level of competence. Another requirement is acquisition of professional culture which in addition to the aforementioned presupposes, having skills in implementation of the acquired knowledge, creative abilities and abilities to learn new technologies. Creative abilities are a mandatory and a determining element of professional culture. Even standard definitions of specialists, such as engineers as a professional group, presuppose ability to perform creative and research activities as one of the major attributes of this group along with the special education and qualification. As regards the augmented product, external factors which share a specialist's image are considered along with the listed characteristics. Any professional activities presuppose interaction in a local or global community. These social relations may form 
accidentally and unintentionally or be deliberate from the point of view of their potential outcome. Thus professional knowledge and technologies are not only a part of single-purpose culture anymore. They become a part of culture shared by all members of society and involving the most sustained and typical models of behavior, ideas and values. The specialist's model under the consideration enables the university to gain a keener insight into the specific character of demand for specialists with higher education and achieve the maximum possible match between the models of a graduate and a sought-after specialist which in its turn, helps to boost the competitive ability of the university. Formation of the mechanism of the university graduate's evaluation may be described by a logic model. For this purpose we will use one of brand management categories - use value rate [4]. $116 \mathrm{UVR}=\mathrm{a}$ set of actual properties (indicator characterizing a graduate) $\leq 1$ (1) 117 a set of desirable properties (indicator characterizing a specialist) 118 If UVR $\rightarrow 0$, it shows the lack of the graduate's competitive ability in the labor market. If UVR $\rightarrow$ 1 , then on the contrary, it is an indicator of a young specialist's competitive ability. User value rate is a ratio between a set of knowledge, skills and personal characteristics of the graduate and the needs of the employer expressed in the form of a specialist's model. User value rate is a unity of professional, as well as personal and psychological qualities of a graduate. These qualities involve the existing individual characteristics of a person and those ones shaped by the university and aimed at meeting specific requirements of the labor market. UVR is undergoing a constant development. The essence of this indicator is that the graduate's model involving a number of factors should ideally be close to the specialist's model. However, the logic model does not fully reflect the graduate's potential and the degree of demand for him/her in the labor market. In the context of brand management, the indicator of user value rate of the branded product is reviewed as follows [5]: Brand $\mathrm{UVR}=$ product features + augmented product features (2) primary and secondary needs. In this model, augmented product features imply design, trademark, image, package and delivery. Thus, by determining the essence of the social importance and significance of the brand, it is possible to justify a higher price of the branded product and prove to the consumer the advantages of a brand over non-branded goods and services. To optimize the estimate of a university graduate's use value, it is important to have a keen insight into all aspects of the employer's and the specialist's needs. Such aspects include confidence in the university; social value of the university's image in the labor market, graduate's awareness of his or her social importance, etc. When estimating a graduate's use value, it is necessary to use information received from the employers in order to provide a more precise list of factors of a specialist's model. The survey has the following advantages: firstly, requirements for a specialist's model are elaborated more thoroughly; secondly, significance of the parameters is defined; thirdly, evaluation of the university graduate is provided; and fourthly, image of the educational establishment is assessed.

\subsection{Who Needs a Young Specialist?}

As it was mentioned above, evaluation of the demand for graduates in the labor market is a rather challenging task. To obtain more trustworthy information, the author has used the official data of the Central Statistical Bureau of Latvia and the State Employment Agency. To evaluate the competitive ability of graduates in the European labor market, data of the different European employment agencies have been used. Assessing young specialists' level of training for work in the selected specialty area, most employers specified that $90 \%$ of individuals with higher education have a good theoretical foundation, but $43 \%$ of graduates lack practical skills (Chart 1) [6]. The major drawbacks of higher education are a gap between theoretical knowledge and practical skills, as well as a low level of practical skills. Employers point out that university graduates lack sufficient initiative and interest in obtaining specific results.

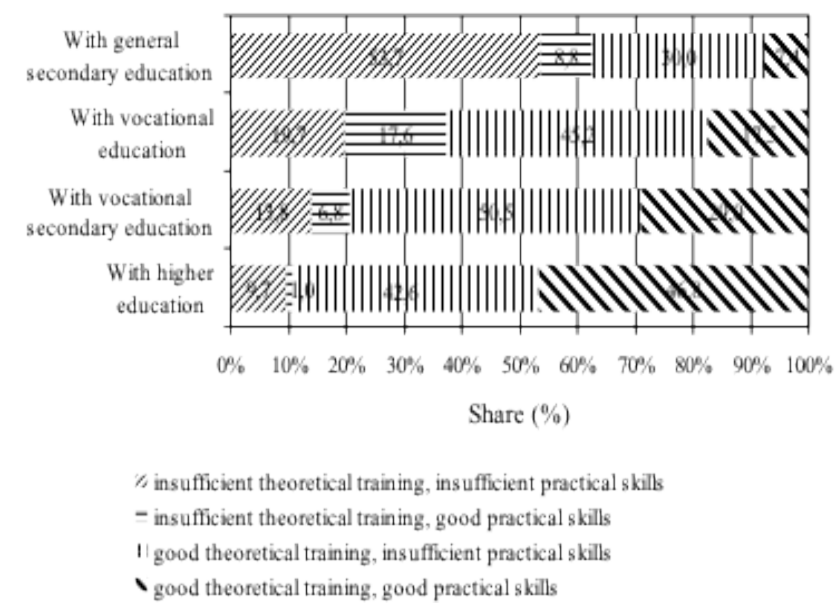

Figure 1. Quantity survey of employers from the labor market research "Detailed Research of Labor Force

Other lacking factors are motivation, desire to learn and work and capability of taking own decisions. Very often university graduates have excessive self-esteem and unjustified ambitions, not least because of deficiency of skilled labor in Europe and in Latvia in particular. One of the main drawbacks of all graduates is the lack of skills to adapt to work in new conditions. In today's circumstances of market economy which is aimed at adoption of new knowledge and technology, this tendency exhibited by the present-day university graduates is assessed as rather dangerous. An individual's ability to adapt to changes in the labor market is the primary survival factor of today. As a result of analysis of data of the Central Statistical Bureau of Latvia and a survey of unemployed university graduates, the following areas of specialization have been selected as potentially less sought after in the labor market:[7]

- Bachelor of Economics - 30 graduates

- Bachelor of Business Administration/Business Management -25 graduates 
- Lawyer/ Bachelor of Law - 24 graduates

- Teachers (different programmes) - 21 graduates. Monitoring of competitive ability of different universities has been performed as well:

- University of Latvia - 56 graduates

- Baltic International Academy - 38 graduates

- Daugavpils University - 38 graduates

- Riga Technical University - 31 graduates

- Latvia University of Agriculture - 25 graduates.

Graduates of the following study programs work in their respective specialty areas most often:

- Architecture and Construction (90\%)

- Education $(86 \%)$

- Health Care (81\%)

Less often:

- Arts and Humanities (54\%)

- Production and Processing (59\%)

- Engineering and Technology $(60 \%)$.

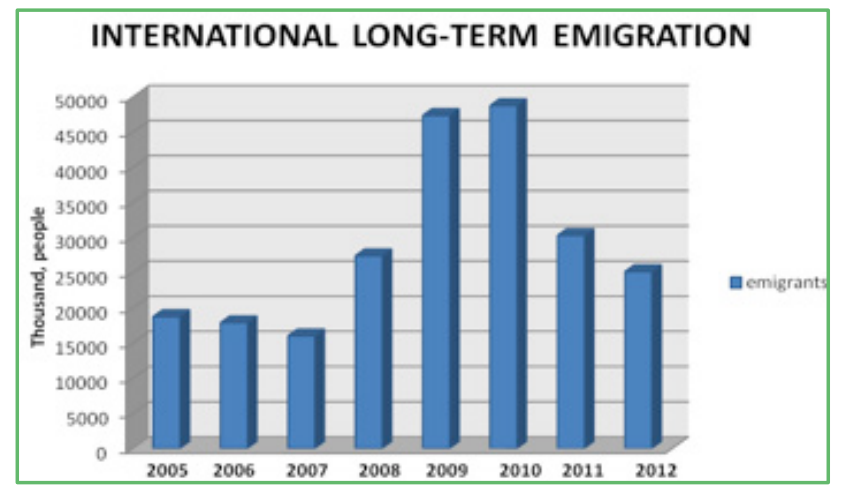

Figure 2. International long-term emigration [2]

According to the data of statistics, over the last five years, the number of people with the higher education, who are registered at the labor exchange, is constantly growing. At the end of 2012 the number of unemployed people with the higher education was 12998 (12, 5\%), in June of 2013 already $-13,5 \%$ of the total number of the unemployed people. In such situation, many young professionals decide to leave the country. The share of men and women of the total number of emigrants in 2012 was about the same respectively $49,8 \%$ and $50,2 \%$. More than half of the emigrated are the residents at the age of 20 to 39 years $(52,6 \%$ of men and 50, $4 \%$ of women). Most $-66,5 \%$ of the women, who emigrated, were women of reproductive age $(15-49)$. Of the total number of emigrants 11,1 thousand or $44,1 \%$ were Latvians and 8, 900186 thousand or 35, $3 \%$ - were Russians. The analysis of the total flow of emigrants shows that in 2012 one in three, who had left Riga was the inhabitant of Riga. Analyzing the share of emigrants who lived in particular region, it was found that most left Kurzeme and Latgale $-1,4 \%$ of the residents of region and the least from the Riga region - only $1 \%$ of the residents. According to the data of management of migration over the last 8 years on the permanent place of residence in the countries of Europe have left 231, 676 people. Among them $65 \%$ are with the higher education. Leave mainly young people under 35 years of age. Making a decision about the trip, people usually are guided not only by one motive, but by several ones: [8]

Statistics shows a steady increase in the number of people with higher education who has registered at the unemployment office over the past 8 years. At the end of 2008, there were 12000 unemployed with higher education. This is a $14 \%$ increase from 2007 . Today, the unemployed people with higher education account for $16 \%$ of all unemployed registered in Latvia (76435 people as at the end of 2008). [09] In this situation, many young specialists take a decision to leave the country. Data of the Office of Citizenship and Migration Affairs shows that 2205 people have left this country for permanent residence in other European countries over the past 3 years. Of these people $65 \%$ are with higher education. [10] The majority of people who leave are young individuals under the age of 35 and below. When taking the decision about relocation, people, as a rule, are guided by at least several motives:

- Continuing education (unfortunately, in this country there is not a single sector of economy with a leading development position);

- Practical experience (for many individuals, additional training or internship in a company abroad is a springboard for career advancement in the home country). Individuals with such experience have much better chances of finding a good job in this country in comparison with other applicants. In the social context, the specialist gains an opportunity to work in a multinational environment which enables $\mathrm{him} / \mathrm{her}$ to develop more flexible communication skills);

- Learning a foreign language (this is the only argument expressed by each and every one leaving abroad for a long period);

- Financial problems.

In 2010, the Employment Agency carried out a survey "What makes people get interested into working abroad!" 1014213 people of different age took part in the survey. 58\% of the respondents aged between 18 and 24 would like to leave and work in their area of specialization. $33 \%$ claimed that they would definitely go abroad to continue education or to work. $17 \%$ would like to leave abroad for life, while $77 \%$ expressed a desire to leave for an indefinite period and definitely come back. The majority of the respondents were certain that they would have to work in unskilled jobs.

The determining factor of staying abroad is the status. Any changes in the status automatically modify the conditions of staying on the territory of the country. After finishing studies or expiration of the employment contract, the individual has faced the reality of life of an ordinary foreigner in a "developed capitalist country". There is no doubt that the rule that "a good specialist can always find a job" holds true. However, there are many legal procedures to complete and dozens of papers to approve in order to get the work permit. European labor market is very competitive. Employers prefer to hire nationals of their own country to avoid, among 
other things problems with the procedure of hiring a foreigner. One should also take into consideration that we are referring to a young specialist whose professional experience is not sufficient due to age. Finally, no matter how well the foreign applicant masters the language of the respective country, the native speaker will always have better language skills, and the employer's choice between the two is obvious. Unfortunately, there is no precise statistics as to the areas where young specialists work abroad and as to the positions they hold. The official data provides only a general picture of the competitive ability of Latvia's nationals in the EU countries. Mainly, they are sought after in tourism (hotels), catering (restaurants) and trade. Health professionals from Latvia also have a high rating. Skilled programmers have no problem in finding a job as well. [11] Over the next decades, Europe is forecast to face a serious shortage of working age population. European population is ageing rapidly. Brain drain of young specialists from Latvia and other countries is expected to continue. Nevertheless, the growing trend of brain circulation - the exchange of specialists instead of the one-way process of brain drain - is viewed as a positive factor

Table 1. Reasons encouraging an individual toleave abroad

\begin{tabular}{|c|c|}
\hline High income & 44 \\
\hline Gaining job-related experience & 16 \\
\hline Prospects for career advancement & 8,6 \\
\hline Work with new technologies & 7,2 \\
\hline Political and economic situation in Latvia & 5,9 \\
\hline Language acquisition & 5 \\
\hline Higher living standards & 3,3 \\
\hline Other reasons & 10 \\
\hline
\end{tabular}

\section{Conclusion}

The freedom of choice of additional education, strategy of individual career, country of studies or residence becomes a norm, and this suggests optimism. To enhance the competitive ability of Latvia's university graduates, the following important tasks should be solved:

- To offer the students an opportunity of developing specific ideas, to encourage their writing of graduate qualifying papers which may be put into practice, thus contributing to formation of a system which reviews the solving of professional problems;

- To expand the applied scope of scientific development; to provide technical and material support to the activities of students and instructors who develop scientifically innovative projects;

- To strengthen the links between the education process and practical work; to increase employers' motivation towards the cooperation with universities regarding training of competent specialists of the highest qualification;

- To shape government procurement in education and promote the development of education in accordance with the labor market trends;

- To expand research regarding the activities of university graduates: whether they work in their respective specialty areas, who paid for their education, whether such specialists will be in demand on the market in 2 or 3 years, as Latvia still lacks consistency between demand and supply in the sphere of education and needs of the labor market.

\section{Acknowledgements}

We are very grateful to experts for their appropriate and constructive suggestions to improve this template.

\section{REFERENCES}

[1] Central Statistical Bureau of Latvia,2013, Online available fromwww.csb.gov.lv

[2] Central Statistical Bureau of Latvia,2009, Online available fromwww.csb.gov.lv

[3] Latvian State Employment Agensy, Online available from www.nva.gov.lv

[4] Philip Kothler,Principles of Marketing, Ninth edition, Pearson Education, 2011

[5] Pol Temporal "Advanced Brand Managament from Vision to Valuation”, 2002

[6] Darba tirgus pētījums,,Profesionālās un augstākās izglītības programmu atbilstība darba tirgus prasībām”. LU, 2007.

[7] 2010.gada NVA pētījums „Absolventu - bezdarbnieku aptauja".

[8] Izglīitības attīstības pamatnostādnēs 2007.-2013.gadam.

[9] Доклад международной комиссии по образованию, представленный ЮНЕСКО «Образование: сокрытое сокровище». - М.: ЮНЕСКО, 1997.

[10] Перекалина Н.С.: "Качество в системе маркетинга", Москва, “Система", 1992 г.

[11] The Office of Citizenship and Migration Affairs, Online available fromhttp://www.pmlp.gov.lv/lv/sakums/jaunumi/p ublikacijas/petijumi/ on 12 May, 2012.

[12] WENDLANDT, N. M.; ROCHLEN, A. B. (2008) "Addressing the college-to-work transition: Implications for university career counselors". A: Journal of CareerDevelopment, 35, pp. 151-165.

[13] HERNÁNDEZ MARCH, J.; MARTÍN, M.; LEGUEY, S. (2009) "Graduates' skills and higher education: the employers" perspective". A: Tertiary Education and Management, 15, pp. 1-16.

[14] ANDREWS, J.; HIGSON, H. (2008) "Graduate Employability, 'Soft Skills' versus 'Hard'Business Knowledge: "A European Study". A: Higher Education in Europe, 33, pp. 411-422. 